\title{
Comparative genomics reveals novel genes associated with sensory cilia
}

\author{
B Piasecki ${ }^{1 *}$, T Sasani ${ }^{1}$, B O'Flaherety ${ }^{1}$, T Swords ${ }^{1}$, J Henriksson ${ }^{2}$, E De Stasio ${ }^{1}$, P Swoboda ${ }^{2}$ \\ From Cilia 2014 - Second International Conference \\ Paris, France. 18-21 November 2014
}

\section{Objective}

To identify evolutionarily conserved ciliary genes that facilitate sensory-specific roles.

\section{Methods}

Using reciprocal BLAST analyses, the genomes of organisms that do not make cilia (the plant Arabidopsis thaliana and the yeast Saccharomyces cerevisiae) and that retain motile but not sensory cilia (the moss Physcomitrella patens) were subtracted from the genomes of organisms that have retained sensory cilia (the worm Caenorhabditis elegans and the alga Chlamydomonas reinhardtii).

\section{Results}

These analyses revealed a list of 272 genes that are found exclusively in organisms with sensory cilia but not motile cilia. Importantly, nearly $10 \%$ of the genes on this list have previously been implicated in sensory cilia-specific roles, thus providing numerous internal positive controls that demonstrate this list is enriched with sensory-specific ciliary genes. A subset of uncharacterized candidate genes are currently being studied in C. elegans, which retains cilia exclusively on a set of neurons termed ciliated sensory neurons (CSNs). We are currently generating a number of promoter- and gene-to-green fluorescent protein (GFP) fusion constructs in order to determine the expression and localization patterns of the proteins encoded by these genes. Two of these candidate genes, which are found in worms (C. elegans) and algae (C. reinhardtii) but not in moss (P. patens) have been termed wam-1 and wam-2, respectively. Expression of wam-1 appears to be localized exclusively in the support cells of ciliated dopaminergic neurons, while expression of $w a m-2$ has yet to be fully characterized.

Biology, Lawrence University, Appleton, WI, USA

Full list of author information is available at the end of the article

\section{Conclusion}

Our analyses have successfully revealed novel genes involved in ciliary sensory-specific processes in animals.

\section{Authors' details \\ ${ }^{1}$ Biology, Lawrence University, Appleton, WI, USA. ${ }^{2}$ Department of Biosciences and Nutrition, Karolinska Institute, Huddinge, Sweden.}

Published: 13 July 2015

doi:10.1186/2046-2530-4-S1-P16

Cite this article as: Piasecki et al: Comparative genomics reveals novel genes associated with sensory cilia. Cilia 2015 4(Suppl 1):P16.

Submit your next manuscript to BioMed Central and take full advantage of:

- Convenient online submission

- Thorough peer review

- No space constraints or color figure charges

- Immediate publication on acceptance

- Inclusion in PubMed, CAS, Scopus and Google Scholar

- Research which is freely available for redistribution 